\title{
自動車運転等の禁止等の記載がある医薬品に対する患者への説明体制の構築
}

\author{
田中守
}

\section{Establishing a System for Effectively Explaining Indications for Driving Prohibition Contained in Drug Package Inserts}

\author{
Mamoru Tanaka \\ Division of Pharmacy, Ehime University Hospital; Shitsukawa, Toon, Ehime 791-0295, Japan.
}

(Received September 9, 2016)

\begin{abstract}
To prevent onset and proliferation of public health/hygiene hazards arising from adverse reactions to drugs, physicians and pharmacists in Japan are now required to provide sufficient explanation of precautions when prescribing or dispensing drugs with package inserts indicating that the patient should not drive, or should take precautions when driving, while taking the drug. Additionally, to ensure proper use of drugs dispensed in accordance with the prescriptions issued by physicians or dentists, the Law for Partial Amendment of the Pharmaceutical Affairs Law (Law No. 103 of 2013) mandates that pharmacists must provide necessary pharmacological research-supported information and guidance to the person receiving the prescribed drug. Under such circumstances, at the Ehime University Hospital Division of Pharmacy we have recently standardized our system for in-person explanation of precautions and necessary guidance to be practiced by pharmacists at our hospital's pharmacy with outpatients being prescribed any drug that requires driving caution. We present concrete examples to support that such standardization of the explanation and guidance system at our hospital has reduced the burden placed on pharmacists in their provision of routine clinical services.
\end{abstract}

Key words — package insert; drug label; driver; driving prohibition; prescription medication

\section{はじめに}

2013 年 3 月 22 日に総務省より厚生労働省に対し て「医薬品等の普及・安全に関する行政評価・監視 結果に基づく勧告」1)が行われた。その勧告を受け て，厚生労働省は，都道府県等に対して，医薬品服 用中の自動車運転等の禁止等に関する患者への説明 について通知し，都道府県は医師又は薬剤師からの 患者への説明について適切に行うよう周知した。厚 生労働省から製造販売業者に対して自動車運転等を 禁止するべき，注意するべきであると判断した医薬 品については使用上の注意の改訂を指示した。この 一連の流れは添付文書の使用上の注意に「自動車運 転等の禁止又は注意が必要」とする旨の記載がある 医薬品（以下，運転注意薬）について処方又は調剤

愛媛大学医学部附属病院薬剤部（干791-0295 愛媛県東 温市志津川)

e-mail: matanaka@m.ehime-u.ac.jp

本総説は, 日本薬学会第 136 年会シンポジウムS64 で 発表した内容を中心に記述したものである。
する際は，医師又は薬剤師が患者に対し，必要な注 意喚起の説明を徹底することが責務であると考えら れる。

2014 年 5 月 20 日に悪質・危険な運転者に対する 罰則を強化するために自動車の運転により人を死傷 させる行為等の処罰に関する法律が施行された. ${ }^{2)}$ その後, 2014 年 6 月 12 日より施行された『薬事法 等の一部を改正する法律（平成 25 年法律第 103 号)』到によって医師又は歯科医師から交付された処 方せんで調剤された薬剤の適正使用を図るため, 薬 剂師は必要な情報の提供及び必要な薬学的知見に基 づく指導が義務化された。そこで, 愛媛大学医学部 附属病院（以下，当院）では，院内処方せんで運転 注意薬が処方された外来患者を対象に, 薬剤部空口 において薬剤師が患者に対して対面による注意喚起 の説明及び指導を開始した。この説明・指導業務は 運転注意薬リスト及び説明書面作成, さらに院内処 方せん及び薬袋表記を工夫することで, 説明・指導 体制を構築して標準化を図ったので紹介する. 


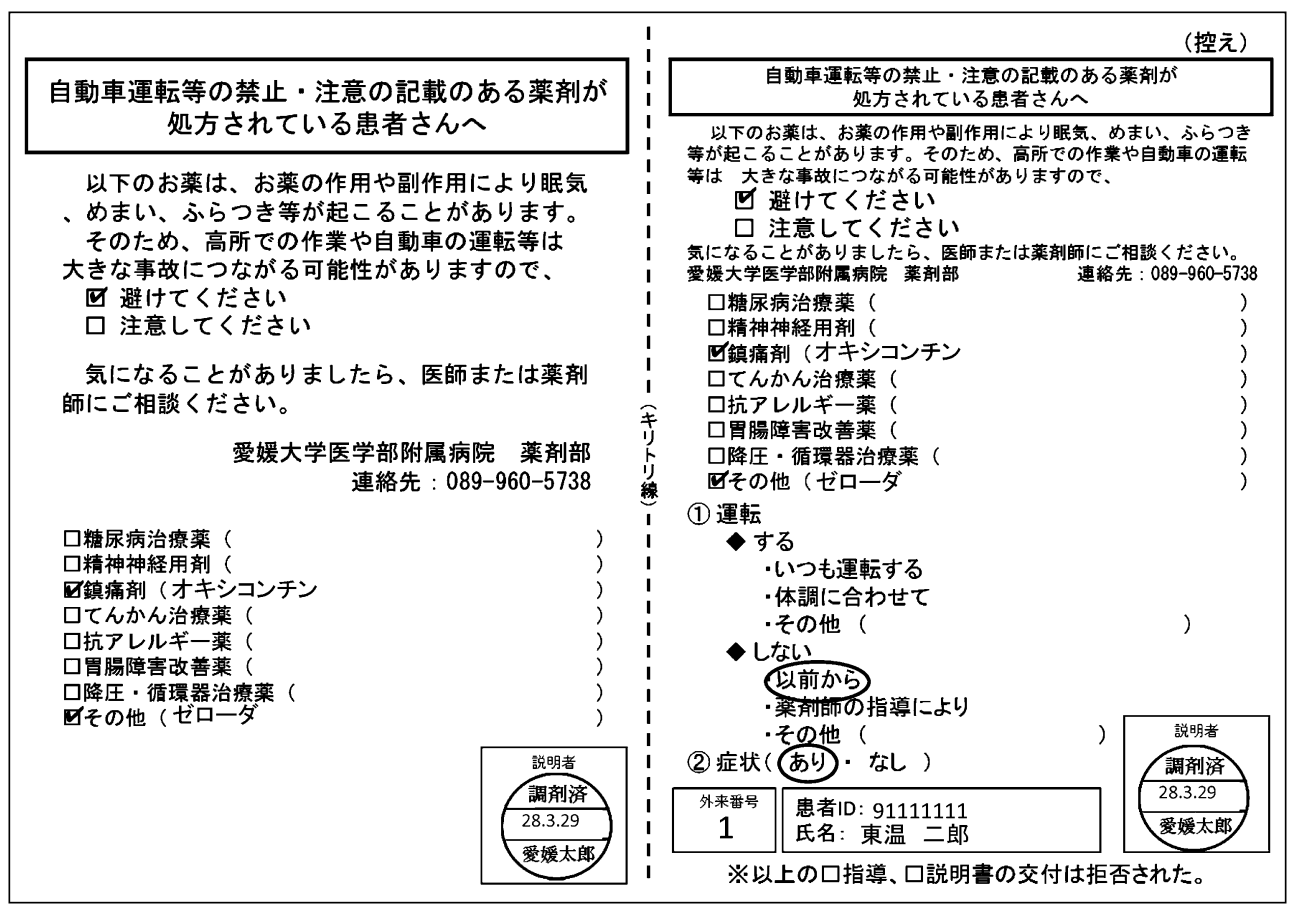

Fig. 1. Patient Instructions

\section{1. 運転注意薬リスト}

院内採用薬の中で添付文書の使用上の注意におい て自動車運転等の禁止又は自動車運転等の際は注意 の記載があるものを抽出するために，医薬品情報サ イトSAFE-DI（https://www.safe-di.jp）の機能を 活用してデー夕を選別して，Microsoft Excel ${ }^{\circledR} を$ 用 いてリストを作成した。作成当初は，採用区分，各 種コード, 販売名, 販売会社等, 一般名, 添付文書 分類など詳細に分類したものを用いていた。 また,

注意喚起別に 7 種類（従事させないこと, 従事させ ないように注意すること, 従事させないように十分 に注意すること，十分に注意すること，注意するこ と・注意させること，説明すること）に色分けされ ていることから, 調剤又は鑑査・確認時に繁雑化し ていた。そこで, 販売名のみ記載し, 注意喚起別に 色分けされている分類を「避ける」と「注意」のみ にすることで簡便化を図った. ${ }^{4}$

\section{2. 院内処方せんと薬袋}

薬剤師が処方薬について運転注意薬の判別が簡便 になるように，院内処方せんには，薬剤名称の左端 の印字に「車」自動車運転等に注意等を要する薬剤,

「ハイ」ハイリスク薬剤,「両」車十ハイリスク薬剤 の略語（「」内の文字）を表記した。また, 薬袋 には服薬中は自動車運転等に注意をする薬剤には
「薬の作用で睡気，めまい等起こることがありま す．高所での作業や自動車運転等は注意してくださ い」, 自動車運転等を避ける薬剤には「薬の作用で 睡気，めまい等起こることがあります。高所での作 業や自動車運転等は避けてください」を記載した. ${ }^{4}$

\section{3. 患者説明書}

当院薬剂部空口において自動車運転等の禁止・注 意薬が院内処方された患者に対して服薬説明する患 者説明書を作成した。患者説明書は A4 サイズ，中 央の切り取り線から切り取ることで, 左側半分は説 明後の患者に交付し, 右側半分は説明後の控えとし て電子カルテに記録・保管する 2 つ目的を持つ (Fig. 1). 該当項目にチェックして運転注意薬の名 称を記入して薬剤部空口において対面により説明・ 指導する。患者説明書は, 患者説明時にチェック ボックスにより確認することで標準化を図った. ${ }^{4)}$

\section{4. 患者説明書チェックルール}

薬剤師の経験年数にかかわらず薬剤師が統一した 患者説明書の確認をするため, 手順の標準化を図る 必要性がある，そこで，患者説明書を記入する 5 項 目 (1)麻薬は “鎮痛薬”に含む, (2)止瀉薬は “胃腸 障害改善薬”に含む, (3)不整脈薬, 心不全薬等は “循環器治療薬”に含む, (4)抗がん剂は“その他” として商品名を記入する, (5)は, (1)から (4)以外で 


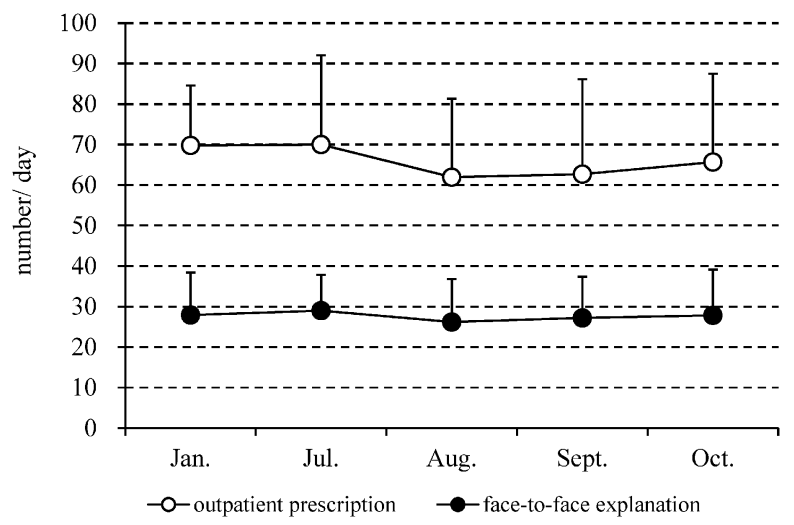

Fig. 2. Per Day of Number, Outpatient Prescription, Faceto-face Explanation of Precautions and Guidance in Hospital Pharmacy from June to October 2014 by Month Value represents the mean \pm S.D.

迷つた場合 “その他”として商品名を記入する）の 患者説明書チェックルール（以下，チェックルール とする）を設けた.

\section{5. 運用評価}

病院薬剤部で調剤する外来患者の処方せんにおい て, 約 4 割が「自動車運転等の禁止又は注意が必要」 医薬品を含んでいる（Fig. 2)。この処方せんを対 象として，運転注意薬リストに基づいて患者説明書 を用いてチェックルールを遵守し，監査業務と説明 業務にかかつた時間で評価した，その結果，月別の 1 人当たりの鑑査時間は, 6 月が $4.3 \pm 1.3$ 分, 7 月 が $3.6 \pm 0.6$ 分, 8 月が 3.4 分 \pm 0.7 分, 9 月が 3.4 分 \pm 0.6 分で, 10 月が 3.6 分 \pm 1.1 分, 6 月と比較し
て 7 月，8 月及び 9 月，10月において短縮が認めら れた (Fig. 3)。また，説明時間は， 6 月が $2.9 \pm 0.8$ 分, 7 月が $1.9 \pm 0.3$ 分, 8 月が 2.0 分 \pm 0.5 分, 9 月 が 1.8 分 \pm 0.3 分, 10 月が 1.6 分 \pm 0.2 分であった.

6 月と比較してすべての月で短縮が認められた (Fig. 3)。特に 7 月の運転注意薬リスト及び患者説 明書の改訂，チェックルールによって説明内容が統 一されたことで説明に要する時間の短縮につながつ たと推察する.4)

\section{6. まとめ}

今回，われわれが構築した運転注意薬の説明体制 は，一連の薬剤業務の標準化を図り，効率化につな げることで病院薬局空口での服薬支援業務負担を軽 減できる有用な方法であることが示唆された. ${ }^{4)} ま$ た，保険薬局における患者満足度の研究では，「服 薬指導」,「薬剂師の対応」,「待ち時間」などが患者 評価に影響が高かったことから, ${ }^{5)}$ 新たな取り組み である運転注意薬に関する説明は，患者にとっても 有益である可能性が考えられる，外来患者の理解度 の向上にはパンフレットの構成や双方向コミュニ ケーションが重要であるとの報告がある。 ${ }^{6)}$ さら に, 外来患者のアドヒアランス向上には, 生活リズ ムを考慮した服薬指導やよりよい信頼関係の構築, 患者への情報提供が重要であるとの報告もある. ${ }^{7)}$

自動車運転等の禁止等の記載のある医薬品を処方 又は調剂する際は, 薬剤師からの患者に対する情報 提供及び指導義務をすることが課せられた。悪質・

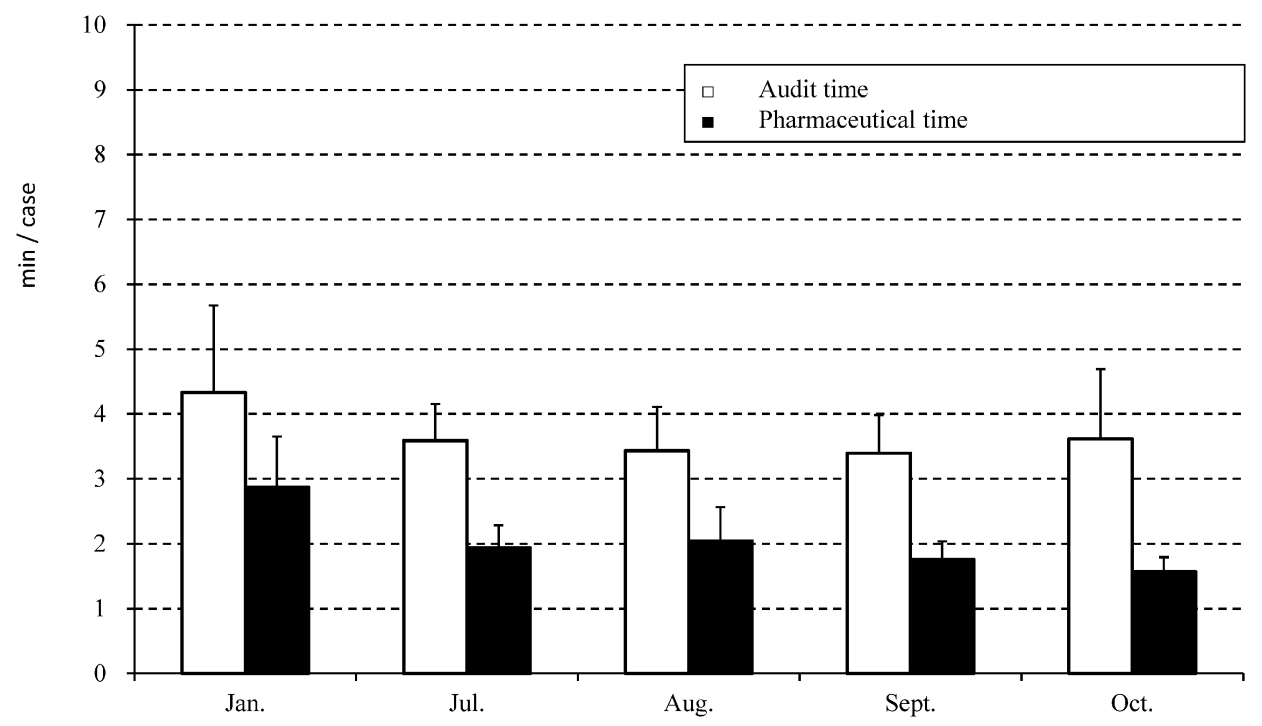

Fig. 3. Monthly per Case Audit Time and Pharmaceutical Time June-October 2014 Values represent the mean \pm S.D. 
危険な運転者に対する罰則を強化するために自動車 の運転により人を死傷させる行為等の処罰に関する 法律が危険運転致死傷として新設された。車の運転 は日常生活や仕事に欠かせない人，必要な通院手段 でもあるかもしれない. 服用した医薬品によって, 個人差，また同一個人によっても体調により運転に 支障を来すか否か左右されることもある。，一方で薬 の服用によって運転に支障を来す，あるいは可能性 がある場合など，適切な指導義務をはたしていなけ れば，重大な事故が発生することがあれば刑事告発 や民事責任を追及されることになるかもしれない。 あわせて，患者が服薬拒否行動にならないように十 分に配慮が必要である.

当院では，病院方針として「自動車運転等の禁止 等」の記載がある医薬品を服用している患者さんへ の指導と記録を整備することになった，病院は患者 を守るとともに，医療を提供する側も守らなければ ならない，薬剤の適正使用を図るため，薬剤師は必 要な情報の提供及び必要な薬学的知見に基づく指導 が義務化された。われわれの指導及び記録の標準化 の取り組みは，業務の効率化によって医薬品適正使 用を推進し，将来において遡及的な調査に対して適 切に対応できると考える.

今後の課題として, 多職種が連携して, 生活環 境，病気の背景や人間関係を理解し，患者の抱えて いる問題に対して全人的（身体的，精神 - 心理的, 社会的）にアプローチすることや患者自らの問題を 自分で解決できるようにするために，患者に本来備 わっている能力を引き出すよう働きかける服薬支援 が望まれる。

利益相反＼cjkstart開示すべき利益相反はない.

\section{REFERENCES}

1) Ministry of Internal Affairs and Communications. "Administrative evaluation and monitoring on the dissemination and safety of drugs."': 〈http://www.soumu.go.jp/menu news/s-news/000071649.html $\rangle$, cited 14 June, 2016.

2) "Law on Punishment of Acts to the death or injury of a person by driving a car.": 〈http:// www.jtsa.or.jp/topics/T-247.html $\rangle$, Japan Traffic Safety Association Web, cited 14 June, 2016.

3) Ministry of Health, Labour and Welfare. "Law for Partial Amendment of the Pharmaceutical Affairs law (Law No. 103 of 2013 ).”: 〈http://www.mhlw.go.jp/bunya/ iyakuhin/ippanyou/131218-1.html $\rangle$, cited 14 June, 2016.

4) Hidaka N., Ochi R., Iwamura Y., Takada Y., Iga K., Fujimoto R., Okino M., Sonoura S., Miyazaki Y., Ido K., Tanaka M., Tanaka A., Araki H., J. Jpn. Soc. Hosp. Pharm., 51, 1245-1248 (2015).

5) Sakurai H., Kawahara S., Tada Y., Nakajima F., Igari T., Momose H., Kondo H., Komori Y., Hayase Y., Yakugaku Zasshi, 127, 11151123 (2007).

6) Katou C., Yamasawa Y., Fugiji R, Nihira A., Sakou K., Norose T., Journal of Japanese Society of Pharmaceutical Communication, 11, 43-50 (2013).

7) Tsuboi K., Teramachi H., Kuzuya Y., Mizui T., Goto C., Tsuchiya T., Jpn. J. Pharm. Health Care Sci., 38, 522-533 (2012). 